\title{
$1: 22124488-22164742$
}

National Cancer Institute

\section{Source}

National Cancer Institute. 1:22124488-22164742. NCI Thesaurus. Code C41920.

Physical location of CDC42_Gene 